Lapuente Pilar (Orcid ID: 0000-0002-8321-2396)

Brilli Mauro (Orcid ID: 0000-0002-2536-5714)

\title{
ADDRESSING THE CONTROVERSIAL ORIGIN OF THE MARBLE SOURCE USED IN THE PHOENICIAN ANTHROPOID SARCOPHAGI OF GADIR (CADIZ, SPAIN)
}

\section{Pilar Lapuente ${ }^{1,2}$, Isabel Rodà ${ }^{2,3}$, Anna Gutiérrez Garcia-M. ${ }^{2}$ and Mauro Brilli ${ }^{4}$}

${ }^{1}$ Petrology and Geochemistry, Earth Sciences Dept. Zaragoza University, 50009 Zaragoza, Spain.plapuent@unizar.es (orcid.org/0000-0002-8321-2396)

${ }^{2}$ Archaeometric Studies Unit, Institut Català d'Arqueologia Clàssica (ICAC), Tarragona, Spain. iroda@icac.cat, agutierrez@icac.cat (orcid.org/0000-0002-1947-4113; ResearcherId AAB-2007-2020)

${ }^{3}$ Dept. Ciències de l'Antiguitat i de l'Edat Mitjana, Universitat Autònoma de Barcelona (UAB), Spain. isabel.roda@uab.es

${ }^{4}$ Istituto di Geologia Ambientale e Geoingegneria - CNR, 00015 Roma, Italy. mauro.brilli@,cnr.it

Corresponding author: plapuent@unizar.es

This article has been accepted for publication and undergone full peer review but has not been through the copyediting, typesetting, pagination and proofreading process which may lead to differences between this version and the Version of Record. Please cite this article as doi: 10.1111/arcm.12623 


\section{ABSTRACT}

Dating from the $5^{\text {th }}$ century BC, two Phoenician anthropoid sarcophagi, a male and a female found in Gadir (Cadiz, Spain), are so far the most ancient marble sculptures found in the Iberian Peninsula. The identification of the source of the marble used to produce them has been a subject of controversy for several decades and has recently resurfaced when it was published that they were made by Phoenician artisans using Iberian marble from Macael. This identification is unreasonable not only from an archaeological point of view nor has it been supported by any analytical data. On the contrary, as the sarcophagi belong to an Eastern Mediterranean Sidonian production, their raw material is most likely to be GreekMinor Asian in origin. In order to shed light on this dispute and objectively resolve their marble provenance, a multi-method analytical approach has been carried out. Optical microscopy, Cathodoluminescence analyses and $\mathrm{C}$ and $\mathrm{O}$ stable isotopes, clarify their marble provenance confirming that both singular sarcophagi were carved in a Cycladic marble, in accordance with their Sidonian style.

Keywords: Phoenicians, sarcophagi, marble, archaeometry, Paros, Macael, Iberia

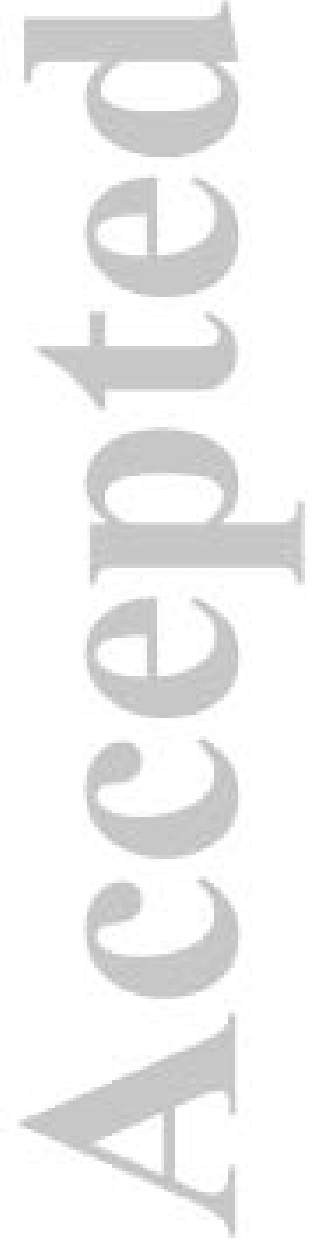




\section{INTRODUCTION}

Archaeological context, stylistic description and parallels

Gadir, which later became Roman Gades and is today the city of Cadiz, was the oldest and most important Phoenician colony in the southwest of the Iberian Peninsula (Aubet, 2009; Bernal et al., 2019; Botto, 2014; Celestino and Rodríguez, 2018; Niveau de Villedary, 2019; Ruiz Mata, 2018). Two of the most singular pieces discovered in this colony are a male anthropoid sarcophagi (found in 1887) and a female (found in 1980), both on display at the Archaeological Museum of Cadiz (Fig. 1A). The sarcophagi from Cadiz are so far the most ancient marble sculptures found in the Iberian Peninsula and date back to some time within the $5^{\text {th }}$ century BC. Their stylistic features match those of the ancient Saida (modern Sidon) productions, from which the most impressive example is the one held by the Museum of Beirut (Ford collection and new finds) (Kukahn, 1955). They are, thus, the westernmost finds of this Phoenician production, since other examples have been found in ancient Phoenicia and elsewhere in the Mediterranean basin, especially from Cyprus to Sicily (Kukahn, 1951, 27; Buhl, 1991; Georgiou, 2009; Leonardo, 2009; Mustafa, 2014, 60-63); those from this last location are two female sarcophagi found in 1695 and 1715 respectively, in the surroundings of Pizzo Cannita (Portella di Mare), currently at the Archaeological Museum of Palermo.

The discovery of the male sarcophagus in the place of Punta de Vaca caused a huge impact and it sparked the foundation of the Archaeological Museum of Cadiz. This sarcophagus was soon object of several publications (Rada y Delgado, 1887; Rodríguez de Berlanga, 1891, with meritorious photos of that time; Hübner, 1888). In point of fact, it not only caught the attention and interest of scholars from several countries (Kukahn, 1951) ${ }^{1}$, but has also been included in relatively recent repertories (Frede, 2000, 2002; Lembke, 2001) ${ }^{2}$ as well as in a $\mathrm{PhD}$ thesis on Phoenician anthropoid sarcophagi (Mustafa, 2014).

The female sarcophagus was found much later on, on the $26^{\text {th }}$ September 1980 , inside a rectangular chamber built with local "ostionera" stone whose ashlars were adapted to the outline of the sarcophagus. Its interior, excavated by the Archaeological Museum of Cadiz, provided highly interesting materials (Corzo, 1979-1980) subsequently echoed by the specialized literature (Blanco, 1981; Blanco and Corzo, 1981; Chiera, 1981) as well as

\footnotetext{
${ }^{1}$ For this sarcophagus historiography and literature, cf. ALMAGRO et al. (2010), 358, note 7.

${ }^{2}$ For the male (Frede 2000, 62, sheets 134-136; Id., 2002: 26-27, 53-54, sheets 3c, 8b; Lembke 2001, 120).
} 
reported in international repertories (Buhl, 1991; and those mentioned above for the male one $)^{3}$.

Only a mere brief description of both sarcophagi, resulting of the autopsy carried out the $29^{\text {th }}$ $30^{\text {th }}$ July 2018, will be presented here, since they have already been described and discussed at length elsewhere (Almagro et al., 2010).

The male sarcophagus depicts a mature bearded person; its maximum length is $220 \mathrm{~cm}$. and despite being well preserved, some parts show the effects of corrosion. The case and the lid are carefully polished except for the head, and four protrusions on the lid ensure its perfect fitting: two at each side of the body near the arms, one behind the head and the fourth one underneath the platform on which the feet are resting. Toothed-chisel marks can be seen on the two lateral protrusions and on the base below the feet.

The hair, fixed in three levels of little curls as little circular bundles in relief, frames the face and covers the ear pinna. The forehead is smooth, the nose straight and the nostrils are marked with longitudinal orifices. Almond-shaped eyes, with the high relief contour of the eyelids particularly clear on the left one. Full lips, partly hidden by the straight moustache that joins the S-shaped curls of the beard; these curls overlap in several levels, thus completely covering the chin and neck. It is worth mentioning that bearded figures are uncommon in this type of sarcophagus, a fact that seems to link this one to a tradition perhaps connected with the Hermes of Alcamenes (Almagro et al., 2010, 365-367). (Fig. 1B).

The body is covered with a fine tunic, apparent at the feet. The arms, in low relief: the right one, practically straight along the body, has a clenched fist and only shows the thumbnail in profile; the left one, bent in a right angle, holds a circular fruit (maybe a pomegranate) with the half-opened hand in which four of the fingers have been worked and the nails of the three first marked with discreet semi-circular incisions (Fig. 1C). The feet are bare and in low relief; the toes are carved symmetrically and with the second one diverging from the big toe. The toenails are well marked and it even seems that there was an attempt to suggest the cuticle, especially in both the big toes; the phalanges are indicated by straight cuts but they are not marked on the fingers. The surface where the feet rest is polished except on the front side. There are very few remains of coloring, which were actually much clearer in the head

\footnotetext{
${ }^{3}$ For the female (Buhl 1991, 680; Frede 2000, 147-149, sheets 137-139; Id. 2002, 50; Lembke 2001, 119, sheets 56 a-d and 57 a; Mustafa, 2014).
} 
and the feet when it was discovered (Rodríguez de Berlanga, 1891, 296; Almagro et al., 2010, 360-362).

The female sarcophagus has a maximum length of $216 \mathrm{~cm}$. It is in a good state despite having suffered some fractures when it was discovered (Corzo 1979-1980); some of the cracks have been repaired, such as a vertical one affecting the right side (Fig. 1D).

The surface has been carefully smoothed and polished, apart from the hair since the three lines of little curls were actually ground with a fine punch (Fig. 1E). This type of hair is found in other sarcophagi such as, for example, one belonging to the Ford collection at the Museum of Beirut ${ }^{4}$. The rear part of the case is also completely polished although to a lesser degree, while the lid is unpolished to the rear of the head where there are clear toothed chisel marks ${ }^{5}$. To ease its perfect fit on the case, the lid has four protrusions worked by toothed chisel, two at each side of the body (just below the elbows), one behind the head and the last one underneath the platform in which the feet are resting. On the feet, the lid is slightly wider than the case and on the sides it presents a meticulous listel to ensure the fit on the lower part of the tunic.

The face is serene, with an edge marking the eyebrows, eyes open and eyelids in relief contouring the almond-shaped ocular globes (Fig. 1E). Straight nose in line with a smooth forehead, matching the type known as Greek profile; nostrils marked with a small orifice by trepan. Full lips and slightly prominent chin (Fig. 1F).

The body is dressed with a light tunic with rectangular neckline and going to the feet, which are worked in high relief, leaving part of the forefoot and the toes uncovered; the rectangular nails are meticulously indicated, as well as the phalanges. The feet are resting flat on the final surface of the lid, where no marks are visible. The two arms are symmetrically bent at the elbows, the right one being slightly more closed than the other; forearms are in high relief. The right hand, whose nails and fingers show the same features as those of the feet, is open while the left one, with the knuckles and veins more marked, holds a perfectly carved alabastron (Fig. 1D); in both hands, the phalanges are also indicated again in high relief.

The Sidonian origin for this kind of sarcophagi is usually well accepted in the literature (Wenger 2003), yet recent finds in the area of Arados/Amrit, in modern Syria, emphasize the

\footnotetext{
${ }^{4}$ Almagro et al., 2010, 382-384, fig. 27 with photos of the sarcophagi from Copenhagen, Paris and the Metropolitan Museum of New York from Lembke 2001, sheet 5c, 35a, 47d, 48a.

${ }^{5}$ On the left part, it exists a small restoration that has even attempted to replicate the tool marks.
} 
importance of these productions also in North Phoenicia (Mustafa 2014; Mustafa and Abbas, 2015). In any case, there is no trace of marble quarries able to provide large blocks throughout the Levantine coast of Phoenicia, so the marble used must have been imported from nearby areas and presumably close to the coast, as already suggested by different papers (Frede, 2002; Faegersten, 2003; Dixon 2013). In this sense, after the discovery of several unfinished examples of sarcophagi on the island of Paros (Schilardi, 1973 op. cit. in van Alfen, 2002), the general opinion of specialists points to this Cycladic island as the place of origin of the marble used to sculpt the Phoenician sarcophagi. Furthermore, the supplying source has been sporadically checked by analytical methods (i.e. by stable isotopic ratio analysis, in Karageorghis, 2000), confirming the Parian origin of the marble.

Therefore, it is clear that the sarcophagi from Cadiz were made by Phoenician artisans following the traditional style of the $5^{\text {th }}$ century $\mathrm{BC}$ and, in consequence, at first hypothesis should be considered as very likely the idea of them having been produced and imported from the eastern Mediterranean.

Controversy about marble provenance of the Gadir sarcophagi. Aim of the study

There is no doubt that the marble identification used in archaeological pieces provides valuable information which help to understand the way of life of the ancient communities. Provenance studies facilitate geographical and chronological evidence of man's activities as well as are of considerable value in elucidating economic and social exchange mechanisms. That is why in recent years the scientific community has been paying great attention to the archaeometric study of marble artifacts especially from the Greco-Roman world ( $c f$. the last volumes of ASMOSIA proceedings, Gutiérrez Garcia-M. et al., 2012; Pensabene and Gasparini, 2015; Matetić Poljak and Marasović, 2018).

However, in contrast to the archaeometric approach based on the comparative analyses with marble quarries, there are still a few theorized studies on which the use of local or regional resources is directly assumed, prevailing over the possible imported ones. This is the case of the sarcophagi under consideration. As already mentioned, numerous studies highlight them as the greatest example of the Phoenician culture in the Iberian Peninsula. Nevertheless, among the abundant specific literature, the lack of scientific rigor is surprising when the marble source is discussed, since it had never been the subject of any published analytical study. Very early on, it was noted that the male sarcophagus could be of marble from the 
Aegean islands (Kukahn, 1951), but this hypothesis was not checked. On the contrary, turning to a hypothesis put forward in the early $20^{\text {th }}$ century (Quintero Atauri, 1917, 73, opus cited by Almagro et al., 2010, 359), a few years ago it was suggested that the two sarcophagi from Cadiz could have been carved in Iberian marble from the Almeria region, which was doubtfully assigned to Macael marble (Almagro et al., 2010, 359; 389-390). In the 1980s some disclosure documents (Pastor Medina, 1987) mentioned that the sarcophagi had been observed at the Museum of Cadiz by entrepreneurs and stonemasons that arrived from Macael, one of the most important marble districts in Spain; they concluded that the sarcophagi were undoubtedly carved in Macael marble (Grima Cervantes, 1994), and no one questioned such a resounding statement. Since then, a variety of publications have continued to assign their marble to Macael quarries without further evaluation and only specifying, in some cases, that no analysis was performed (Almagro et al., 2010).

This lack of analytical rigor remains a common practice today, as shown unfortunately by several recently published articles (Carretero Gómez and Aznar Sánchez, 2017; Navarro et al., 2017), one of which even includes specific photographs of both sarcophagi as the best example of the most important representative elements of the ancient use of Macael marble (Navarro et al., 2019). Thus, what appears in previous literature only as a "possible identity" has turned into a "true identity" that is being passed on from author to author, even if it is, in fact, a false one. Furthermore, taking into account that in the $5^{\text {th }}$ century BC the exploitation of the marble quarries of the Iberian Peninsula had not yet begun, the idea of these sarcophagi being carved from Iberian marble is also unreasonable from an archaeological point of view. Indeed, some centuries had still to pass until the opening of these exploitations, as well as to achieve the technology needed to be able to extract blocks of the size required to cut these large sarcophagi of monolithic case and lid.

Consequently, and given the Iberian-marble hypothesis is being stated in some very recent international studies, this paper undertakes the analytical studies needed to shed light on this controversy and objectively resolve the marble provenance of these singular Phoenician sarcophagi of unmistakable Sidonian production. They are analyzed following a wellestablished multi-method approach (Lapuente, 2014) and the results are compared with a large analytical database of Iberian and other classical marbles from the Eastern Mediterranean territories, created over more than three decades. 
The archaeological specimens used were sampled in the 1980s within the framework of a National Research Program, funded by the Spanish Ministry of Culture, committed to the petrographic characterization of ancient quarry samples and their recognition in archaeological stone materials. The obtention of samples was facilitated by the Museum of Cadiz in the 1980s before the restoration of the sarcophagi, and they were entrusted to the Petrology and Geochemistry Department of Zaragoza University. At that time, the unpublished scientific report, based exclusively on petrography, concluded that the sarcophagi were probably imported marbles but with uncertainties about the exact provenance (Lapuente et al., 1987).

\section{METHODOLOGY}

In July 2018, the sarcophagi were meticulously observed, photographed in detail and macroscopically described, including color measurements on both lids and boxes, to characterize the material and compare the marble of both sarcophagi. Although their surfaces are polished, several areas free of oxidations and secondary calcareous deposits were deemed appropriate and, thus, selected to automatically measure their color. The instrument used was a MINOLTA CM-2600d portable spectrophotometer whose SpectraMagic NX 2.5 software obtains different colorimetric parameters, which provides a direct display of CIE color coordinates $(\mathrm{X}, \mathrm{Y}, \mathrm{Z})$ along with CIELAB values $\left(\mathrm{L}^{*}, \mathrm{a}^{*}\right.$ and $\left.\mathrm{b}^{*}\right)$. Three automatic measurements were taken every $0.3 \mathrm{~s}$ in each of the selected areas, using a window of $3 \mathrm{~mm}$ in diameter. Other standard specifications were a D65 illuminant, and a $10^{\circ}$ observer. Both modes, the specular reflectance excluded (SCE) and included (SCI), were simultaneously measured. Complementary information about color measurements is available in Lapuente et al. (2018).

Two analytical techniques, Optical Microscopy (OM) and Cathodoluminescence (CL) were applied to the thin-sections made more than 30 years ago, though their quality is not optimal due to the presence of many bubbles. Various very small chips from both sarcophagi were used to obtain enough powder samples for analyzing the $\mathrm{C}$ and $\mathrm{O}$ stable isotopes. Experimental procedures were carried out according the methodology described elsewhere (Lapuente et al., 2014; Brilli et al., 2015; Lapuente and Royo, 2016) to characterize the mineralogical-petrographic and the CL features (intensity, color and distribution) and to measure the $\mathrm{C}$ and $\mathrm{O}$ stable isotope ratios. 


\section{RESULTS}

\section{Macroscopic characterization}

Visually, the box and the lid of the male sarcophagus (M) look similar: they are both made of a white marble with scarce, very discontinuous, grey veins and sporadic grey spotted zones (Fig. 2A). It is a medium to coarse-grained marble, compact and well crystallized with relatively homeoblastic texture (Fig. 2B). Light-transmitting with a medium halo around (Fig. 2C) and a faintly sulfurous smell when crushed.

The female sarcophagus (F) marble seems, at first sight, whiter than that of the (M) but looking in detail, is white with sporadic spotted grey zones, showing longitudinal and slightly discontinuous grey veins (Fig. 2D) like those observed on the (M) and a yellowish patina. The $(\mathrm{F})$ presents isolated grey grains embedded in a matrix of white grains perfectly visible on the horizontal surface of the lid (Fig. 2E). It is medium to coarse-grained, even sporadically very coarse, compact and well crystallized, but slightly heteroblastic in texture, if compared to the (M) marble. However, light-transmitting-wise its medium halo around (Fig. 2F) is quite similar to that exhibited by the male and it also has a slightly sulfurous smell, when crushed.

\section{Color parameters}

The main color measurements are summarized in Table 1; only the SCI values are shown since they do not differ significantly from the SCE ones. With the object of checking the slight differences in color, visually observed in both sarcophagi, the CIELAB parameters and the minimal and maximum spectral reflectance curves are plotted in Figure 3 . The female exhibits higher values in $\mathrm{L}^{*}$ (D65), ranging from 61 to 74 , compared to the male which approximately varies from 56 to 70 . These values are in agreement with the higher whiteness visually appreciated in the (F) sarcophagi, since is well known the high correlation between the whiteness and L* parameter (Zezza et al., 1999). In the $\mathrm{a}^{*}$ versus $\mathrm{b}^{*}$ graphic both marbles are in the positive space with a higher reddish/yellowish values in the female.

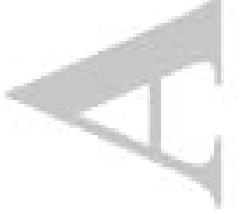


Petrography and Cathodoluminiscence (CL)

The sample of male is a pure calcite marble with isotropic fabric, slightly heteroblastic texture with a maximum grain size (MGS) of $2.5 \mathrm{~mm}$, but is frequently $<2 \mathrm{~mm}$, i.e. of medium to coarse grain. It has a curved and slightly embayed Grain Boundary Shape (GBS) but uncommon straight ones are also shown (Fig. 4a). It exhibits fine but also frequent thick twins, from tabular, occasionally lensed and more frequently patchy straight thick twins (types II, III and IV after Burkhard, 1993). CL-microfacies is very faint but seems to be heterogeneous in distribution (Fig. 4b).

The female sample is, in some aspects similar to that of the male: a pure calcite marble with isotropic fabric, but more homeoblastic at micro scale and with a MGS of $2 \mathrm{~mm}$ (Fig. 4c). However, as shown above, macroscopically its MGS can sporadically reach very coarse grain, up to $4 \mathrm{~mm}$ long. GBS is curved and embayed with frequent thick twins similar to those seen in the male sample. CL-microfacies is of faint intensity and brownish heterogeneous distribution (Fig. 4d).

\section{Isotopic signature}

Their $\mathrm{C}$ and $\mathrm{O}$ isotopic values, in relation to $\mathrm{V}$-PDB international standard, are quite uniform. The values of the male sample are $1.98 \%\left(\delta^{13} \mathrm{C}\right)$ and $-0.28 \%\left(\delta^{18} \mathrm{O}\right)$ and those of the female sample are $1.79 \%$ o $\left(\delta^{13} \mathrm{C}\right)$ and $-0.58 \%\left(\delta^{18} \mathrm{O}\right)$. They are plotted in the isotopic diagram for medium-coarse grained pure calcite marbles which includes the most prominent ones used in classical antiquity in the Eastern Mediterranean territories (data after Gorgoni et al., 2002) and those of Estremoz Anticline, Almadén de la Plata and Macael district in Iberia (data after Lapuente et al., 2000; 2014) (Fig. 5).

\section{DISCUSSION}

Given the recent publications stating that these sarcophagi were made using Macael marble, special attention has been paid here to analytically check this out. Several litotypes of white Macael marble have been distinguished and presented elsewhere (Lapuente, 1995; Lapuente et al., 2000; 2002; Origlia et al., 2012) but they basically consists of three pure calcite 
marbles with few non-discriminatory accessories, which are, in petrography and CL, quite different from both sarcophagi:

(a) White Macael: Homeoblastic mosaic texture; GBS: curved and straight; MGS: 2.2 $\mathrm{mm}$; CL: homogeneous faint purple luminescence and orange in the crystal limits and very small accessories in dark (Fig. 4e).

(b) Macael Río: Heteroblastic mosaic texture, GBS: sutured and curved, MGS: $3 \mathrm{~mm}$; CL: heterogeneous medium to high intensity in dark orange with bright limits, partial relict shadows in some coarser grains (Fig. 4f).

(c) Macael Puntilla: Heteroblastic mosaic texture; GBS: sutured, curved and straight; MGS: 3 $\mathrm{mm}$; CL: Heterogeneous medium to high intensity, with intracrystalline concentric zoned in brown, orange and very bright yellow limits (Fig. 4g).

Moreover, $\mathrm{C}$ and $\mathrm{O}$ isotopes from white Macael varieties are quite uniform, with $\delta^{18} \mathrm{O}$ values ranging from -4.63 to $-2.35 \%$ and very homogeneous $\delta^{13} \mathrm{C}$ (from 2.36 to $3.09 \%$ ). As shown in Fig. 5, the isotopic signature of the analyzed pieces clearly falls outside the Macael isotopic field, but is inside the Prokonnesos-1 and Paros-2(3) isotopic clusters defined by Gorgoni et al., (2002). However, the Marmara Island must be discarded as a marble source due its distinctive CL-pattern in homogeneous dark blue with a clear heteroblastic texture whose bimodal development of calcite provides a mortar texture, which fails to match with those shown by the marbles under consideration. In addition, although the (M) sarcophagi sample falls close to the calcitic Thasos isotopic field, the petrography and especially its CL features, with medium-high intensity (Blanc et al., 2020), completely discard this origin.

On the contrary, after comparison with CL-patterns of published and unpublished marble quarries, the very faint to faint CL-microfacies of male and female are compatible with those exhibited by Paros-2(3) marbles (Fig. 7h). Indeed, although seventy percent of the MGS measurements in Paros-2(3) range from 1.7 to $2.5 \mathrm{~mm}$, they can also reach up to $4.5 \mathrm{~mm}$ long (Gorgoni et al., 2002; Tambakopoulos and Maniatis, 2012), which is consistent with the marble of both sarcophagi, thus helping to identify this marble source as the one used to carve them. Outcropping in the Choridaki and Aghias Minas valleys, to the South of Marathi, in Paros Island, these Paros-2(3) marbles were highly appreciated by both Greeks and Phoenicians, as testified by artifacts from the colonies they established in southern Italy and Sicily (Gorgoni and Pallante, 2000). Consequently, recognizing the marbles quarries from 
Paros as the original source matches well for both sarcophagi in terms of chronology as well, since their use, from Archaic to Byzantine times, is well known (Maniatis and Polikreti, 2000).

\section{CONCLUSIONS}

Despite the slight differences shown by the marbles of each sarcophagus in macroscopic and spectral color measurements, polarized-light microscopy and CL-microfacies, their fairly homogeneous isotopic signature points to a close marble source, which is compatible only with certain imported marbles.

Moreover, $\mathrm{C}$ and $\mathrm{O}$ isotopic values help to determine their marble source. Both are compatible with the same provenance in the Cycladic island of Paros. Male and female samples share mineralogical-petrographic and CL characteristics with Paros-2(3) marbles, in agreement with the archaeological criteria. Therefore, the main Iberian marbles, including those of the Macael district, must be ruled out, thus clarifying the controversy brought about by recent publications.

Finally, it must be emphasized that only the combination of multiple techniques applied to both, the samples obtained from the artifacts and those from ancient marble quarries, can ensure an accurate discrimination in provenance studies. Furthermore, the interdisciplinary study with well formulated hypothesis regarding the marble source based on chronology, style, iconography as well as a good knowledge about the geographical distribution of materials from the most important quarries, lies in a better interpretation of the analytical results.

\section{ACKNOWLEDGEMENTS AND FUNDING SOURCES}

This research is part of the objectives of the project "Officinae lapidariae Tarraconenses. Canteras, talleres y producciones artísticas en piedra de la Provincia Tarraconensis (HAR2015-65319-P, MINECO/FEDER, UE)", and the subsequent project "Sulcato marmore ferro. Canteras, talleres, artesanos y comitentes de las producciones artísticas en piedra en la Hispania Tarraconensis (PID2019-106967GB-I00)" with the additional collaboration of the project "El mensaje del mármol: prestigio, simbolismo y materiales locales en las provincias 
occidentales del imperio romano... (PGC2018-099851-A-I00, MINECO/FEDER, UE)" all of them funded by the Spanish Ministerio de Ciencia, Innovación y Universidades. The authors would like to express their gratitude to the direction management of the Archaeological Museum of Cádiz for the direct access to both sarcophagi and the permission to take photographs. And to acknowledge the use of Servicio General de Apoyo a la InvestigaciónSAI, Universidad de Zaragoza.

\section{REFERENCES}

Almagro-Gorbea, M., López-Rosendo, M.E., Mederos Martín A., Torres-Ortiz M., 2010. Los sarcófagos antropoides de la necrópolis de Cádiz. Mainake XXXII (I), 357-394.

Aubet Semmler, M.E., 2009. Tiro y las colonias fenicias de Occidente, third ed Universitat Autònoma de Barcelona, Bellaterra.

Bernal, D., Vargas, J.M., Lara, M. (Eds.), 2019. 7 metros de la historia de Cádiz. Editorial UCA, Cádiz.

Blanc, Ph., Lapuente Mercadal, M.P., Gutiérrez Garcia-Moreno, A., 2020. A new database of the quantitative cathodoluminescence of the main quarry marbles used in Antiquity. Minerals, 10, 381; doi:10.3390/min10040381.

Blanco, A., 1981. Fenicios de Sidón. A propósito del nuevo sarcófago de Cádiz. Historia 16, $59,122-128$.

Blanco, A., Corzo, R., 1981. Der neue anthropoide Sarkophag von Cádiz. Madrider Mitteilungen 22, 236-243.

Botto, M. (Ed.), 2014. Los fenicios en la bahía de Cádiz: nuevas investigaciones. Fabrizio Serra Editores, Pisa-Roma.

Brilli, M., Giustini, F., Conte, A.M., Lapuente Mercadal, P., Quarta, G., Royo Plumed, H., Scardozzi, G, Belardi, G., 2015. Petrography, geochemistry, and cathodoluminescence of ancient white marble from quarries in the southern Phrygia and northern Caria regions of Turkey: Considerations on provenance discrimination. Journal of Archaeological Science: Reports, 4, $124-142$. 
Buhl, M.L., 1991. Les sarcophages anthropoïdes phéniciens trouvés en dehors la Phénicie, in Atti del II Congresso Internazionale di Studi Fenici e Punici, (Roma 1987), vol. II. CNR, Roma, pp. 675-681.

Burkhard, M., 1993. Calcite twins, their geometry, appearance and significance as stressstrain markers and indicators of tectonic regime: a review. Journal of Structural Geology 15, $351-368$.

Carretero Gómez, A., Aznar Sánchez, J.A., 2017. Las canteras de mármol de Macael. Boletín Geológico y Minero 128 (2), 329-343. https://doi.org/10.21701/ bolgeomin. 128.2.004

Celestino, S., Rodríguez, E. (Eds.), 2018. Actas del IX Congreso Internacional de Estudios Fenicios y Púnicos. Un viaje entre el Oriente y el Occidente Mediterráneo (Mérida 2018). Instituto de Arqueología de Mérida. CSIC - Junta de Extremadura, Mérida [in press].

Chiera, G., 1981. Su un nuovo sarcofago antropoide scoperto a Cadice. Rivista di Studi Fenici 9/2, 211-216.

Corzo, R., 1979-1980. El nuevo sarcófago antropoide de la necrópolis gaditana. Boletín del Museo de Cádiz II, 13-24.

Frede, S., 2000. Die phönizische anthropoiden Sarkophage I. Fundgruppen und Bestattungskontexte. Verlag Phillip von Zabern in Wissenschaftliche Buchgesellschaft, Mainz am Rhein.

Frede, S., 2002. Die phönizische anthropoiden Sarkophage II. Tradition, Rezeption, Wandel, Verlag Phillip von Zabern in Wissenschaftliche Buchgesellschaft, Mainz am Rhein.

Georgiou, G., 2009. Three Stone Sarcophagi from a Cypro-Classical Tomb at Kition. Cahier du Centre d'Etudes Chypriotes 39, 113-39.

Gorgoni, C., Lazzarini, L., Pallante, P., Turi, B., 2002. An updated and detailed mineropetrographic and $\mathrm{C}-\mathrm{O}$ stable isotopic reference database for the main Mediterranean marbles used in antiquity, in: Herrmann J.J. Jr., Herz, N. Newman, R. (Eds.), ASMOSIA 5. Interdisciplinary studies on ancient stone. Archetype Pub., London, pp. 115-131.

Gorgoni, C., Pallante, P., 2000. On Cycladic marbles used in the Greek and Phoenician colonies of Sicily, in Schilardi, D.U., Katsonopoulou, D. (Eds.), Paria Lithos. Parian 
quarries, marble and workshops of sculpture. The Paros and Cyclades Institute of Archaeology, Athens, pp. 497-506.

Grima Cervantes, J., 1994. La explotación del mármol de Macael y de Los Filabres a lo largo de la historia (I): Desde la antigüedad hasta el fin del periodo nazarita”, in: Grima Cervantes, J., Martínez-Cosentino, F. (Dirs), La piedra natural. Su papel en la Historia. Nuevo reto de la minería y la industria en España. Arráez Editores, Almería, pp. 27-42.

Gutiérrez Garcia-M., A., Lapuente, P., Rodà, I. (Eds.), 2012. Interdisciplinary Studies on Ancient Stone. Proceedings of the IX ASMOSIA Conference (Tarragona 2009). ICAC, Tarragona.

Hübner, E., 1888. La Arqueología de España. Sucesores de Ramírez y ca., Barcelona.

Karageorghis, V., 2000. Phoenician marble anthropoid sacophagi and their Parian connection, in: Schilardi, D.U., Katsonopoulou, D. (Eds.), Paria Lithos. Parian Quarries, Marble and Workshops of Sculpture. The Paros and Cyclades Institute of Archaeology, Athens, pp. 469-478.

Kukahn, E., 1951. El sarcófago sidonio de Cádiz. Archivo Español de Arqueología 24, 23-34.

Kukahn, E., 1955. Anthropoide Sarkophage in Beyrouth und die Geschichte dieser sidonischen Sarkophagkunst. Ed. Mann, Berlin.

Lapuente, M.P., 1995. Mineralogical, petrographical and geochemical characterization of white marbles from Hispania, in: Maniatis, Y., Herz, N., Basiakos, Y. (Eds.), The Study of Marble and Other Stones Used in Antiquity. Archetype Pub., London, pp. 151-160.

Lapuente Mercadal, M.P., 2014. Archaeometry on stones. Multi-method approach to investigate stone provenance. Studied cases from Roman Hispanic marmora. Archeometriai Muhely XI (3), 149-58. urn: nbn: hu-4106.

Lapuente, P., Blanc, Ph., 2002. Marbles from Hispania: scientific approach based on cathodoluminescence, in: Herrmann J.J. Jr., Herz, N. Newman, R. (Eds.), ASMOSIA 5. Interdisciplinary studies on ancient stone. Archetype Pub., London, pp. 143-151.

Lapuente, M.P., Cisneros, M., Ortiga, M., 1987. Análisis petrográficos de material arqueológico del Museo de Cádiz. Unpublished scientific report, Petrology and Geochemistry Dept., Zaragoza University. 
Lapuente, P., Nogales-Basarrate, T., Royo, H., Brilli, M., 2014. White Marble Sculptures from the National Museum of Roman Art (Mérida, Spain): Sources of Local and Imported Marbles. European Journal of Mineralogy 26, 333-354. https://doi.org/10.1127/0935$1221 / 2014 / 0026-2369$.

Lapuente, P., Nogales-Basarrate, T., Royo-Plumed, H., Brilli, M., Savin, M-C., 2018. Grey and greyish banded marbles from the Estremoz Anticline in Lusitania, in: Matetić Poljak Poljak, D., Marasović, K. (Eds.), ASMOSIA XI. Interdisciplinary Studies on Ancient Stone. Proceedings of the XI International Conference of ASMOSIA. Arts Academy in Split and Faculty of Civil Engineering, Architecture and Geodesy, University of Split, Split, pp. 391 399. https://doi.org/10.31534/XI.asmosia.2015/02.24

Lapuente, M.P., Royo, H., 2016. Cathodoluminescence for the characterization of ancient marble. Problems and research perspective, in: Ismaelli T., Scardozzi, G., (Eds.), Ancient quarries and building sites in Asia Minor. Research on Hierapolis in Phrygia and other cities in south-western Anatolia: archaeology, archaeometry, conservation. Edipuglia, Bari, pp. 541-548. http://dx.doi.org/10.4475/819

Lapuente, P., Turi, B., Blanc, Ph., 2000. Marbles from Roman Hispania: stable isotope and cathodoluminescence characterization. Appl. Geochem. 15, 1469-1493.

Lembke, K., 2001. Phönizische anthropoide Sarkophage, Damaszener Forschungen 10. P. von Zabern, Mainz am Rhein.

Leonardo, D.L., 2009. Immagine e immagini della Sicilia e di altre isole del Mediterraneo II. Edizioni della Normale, Pisa.

Maniatis, Y., Polikreti, K., 2000. The characterization and discrimination of Parian marble in the Aegean region, in: Schilardi, D.U., Katsonopoulou, D. (Eds.), Paria Lithos. Parian Quarries, Marble and Workshops of Sculpture. The Paros and Cyclades Institute of Archaeology, Athens, pp. 575-584.

Matetić Poljak, D., Marasović, K. (Eds.), 2018. ASMOSIA XI. Interdisciplinary Studies on Ancient Stone. Proceedings of the XI International Conference of ASMOSIA. Arts Academy in Split and Faculty of Civil Engineering, Architecture and Geodesy, University of Split, Split. http://gradst.unist.hr/ostalo/izdavacka-djelatnost/a/view/id/4078 
Mustafa, B., 2014. La imagen de la realeza en la costa de Levante en época persa. Arqueología de los sarcófagos antropomorfos fenicios, PhD Thesis, Universidad de Granada.

Mustafa, B., Abbas, N., 2015. New marble sarcophagus from Syrian coast. Scientific Culture $\mathrm{I} / 1,17-26$.

Navarro, R., Cruz, A., Arriaga, L., Baltuille, J.M., 2017. Caracterización de los principales tipos de mármol extraídos en la comarca de Macael (Almería, sureste de España) y su importancia a lo largo de la historia. Boletín Geológico y Minero 128, 345-393. https://doi.org/10.21701/bolgeomin.128.2.005

Navarro, R., Pereira, D., Cruz, A.S., Carrillo, G., 2019. The Significance of "White Macael" Marble Since Ancient Times: Characteristics of a Candidate as Global Heritage Stone Resource. Geoheritage 11, 113-123. https://doi.org/10.1007/s12371-017-0264-X

Niveau de Villedary, A.M., 2019. La etapa arcaica de la ciudad fenicia de Gadir. Lucentum XXXVIII, 111-138.

Origlia, F., Gliozzo, E., Meccheri, M., Spangenberg, J.E., Turbanti Memmi, I., Papi, E., 2011. Mineralogical, petrographic and geochemical characterisation of white and coloured Iberian marbles in the context of the provenancing of some artefacts from Thamusida (Kenitra, Morocco). European Journal of Mineralogy 23, 857-869.

Pastor Medina, G., 1987. Aspectos históricos de las canteras de Macael Programa de fiestas de Macael. Ayuntamiento de Macael, Almería.

Pensabene, P., Gasparini E. (Eds.), 2015. Asmosia X. Proceedings of the Tenth International Conference. Interdisciplinary Studies on Ancient Stone. L'Erma di Bretschneider, Rome.

Quintero Atauri, P., 1917. Cádiz. Primeros pobladores: hallazgos arqueológicos. Imp. Manuel Alvarez, Cádiz.

Rada y Delgado, J. de., 1887. Noticias. Boletín de la Real Academia de la Historia 10, 337.

Rodríguez de Berlanga, M., 1891. El nuevo bronce de Itálica. Ambrosio Rubio, Málaga.

Ruiz Mata, D., 2018. Gadir, su estructura plural. Un modo de ver su fundación fenicia en el espacio y en el tiempo. Onoba 6, 249-288. 
Schilardi, D., 1973. A new Phoenician Sarcophagus from Paros. American Anthropological Association VI, 466-71.

Tambakopoulos, D., Maniatis, Y., 2012. The search for prehistoric marble sources in the Cyclades, in: Gutiérrez Garcia-M., A., Lapuente, P., Rodà, I. (Eds.), Interdisciplinary Studies on Ancient Stone. Proceedings of the IX ASMOSIA Conference (Tarragona 2009). ICAC, Tarragona, pp. 287-299.

van Alfen, P.G., 2002. Pant'agatha. Commodities in Levantine-Aegean trade during the Persian period, 6-4th century BC. PhD Dissertation. University of Texas at Austin.

Wenger S., 2003. Les sarcophages phéniciens de Sidon. Semestra, Griechische Kunst an orientalischen Fürstenhöfen. Archéologie classique, 1-14.

Zezza, U., Massa, V., Palazzi, S., 1999. Whiteness index characterization for Greek marbles, in: Schvoerer, M. (Ed.), Actes de la Conférence intenationale ASMOSIA IV, 9-13 Octobre 1995, Archéomatériaux- Marbres et autres roches, 191-195.

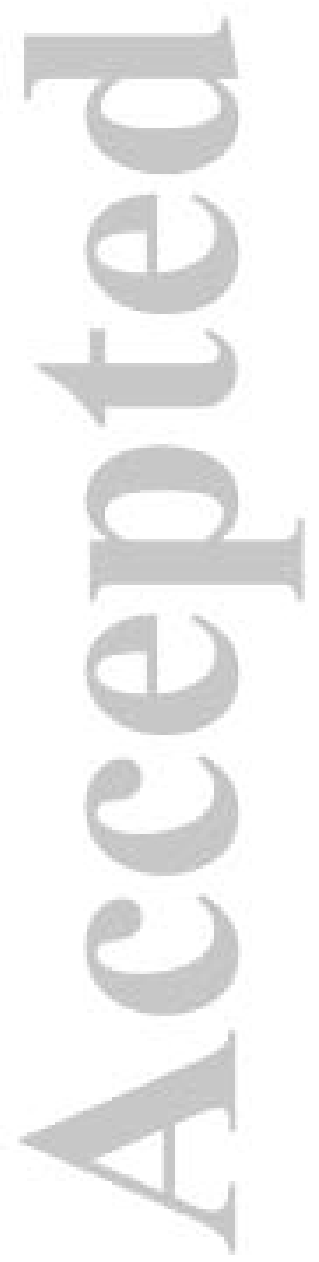


Table 1. Main color measurements obtained with the portable spectrophotometer.

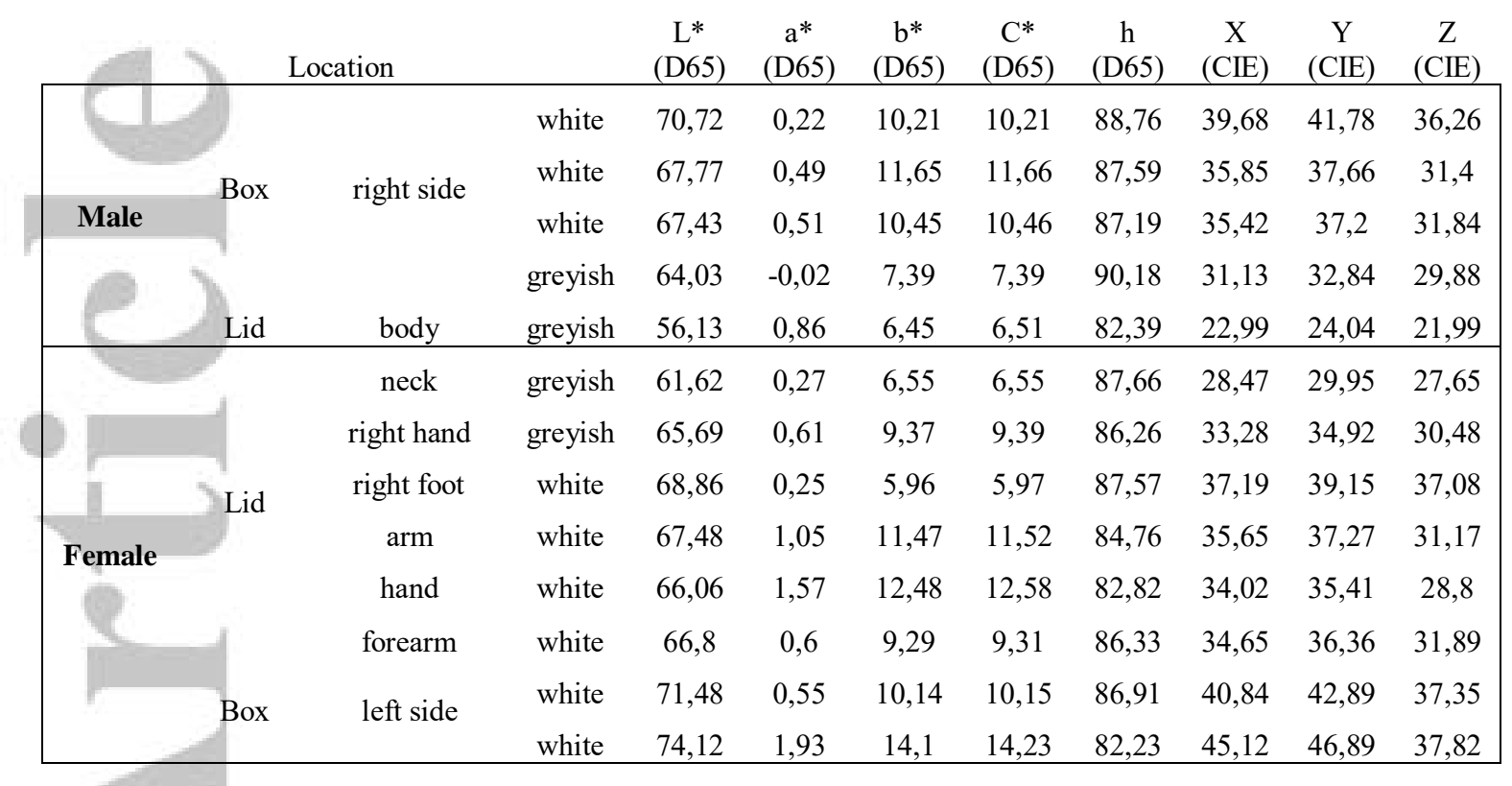




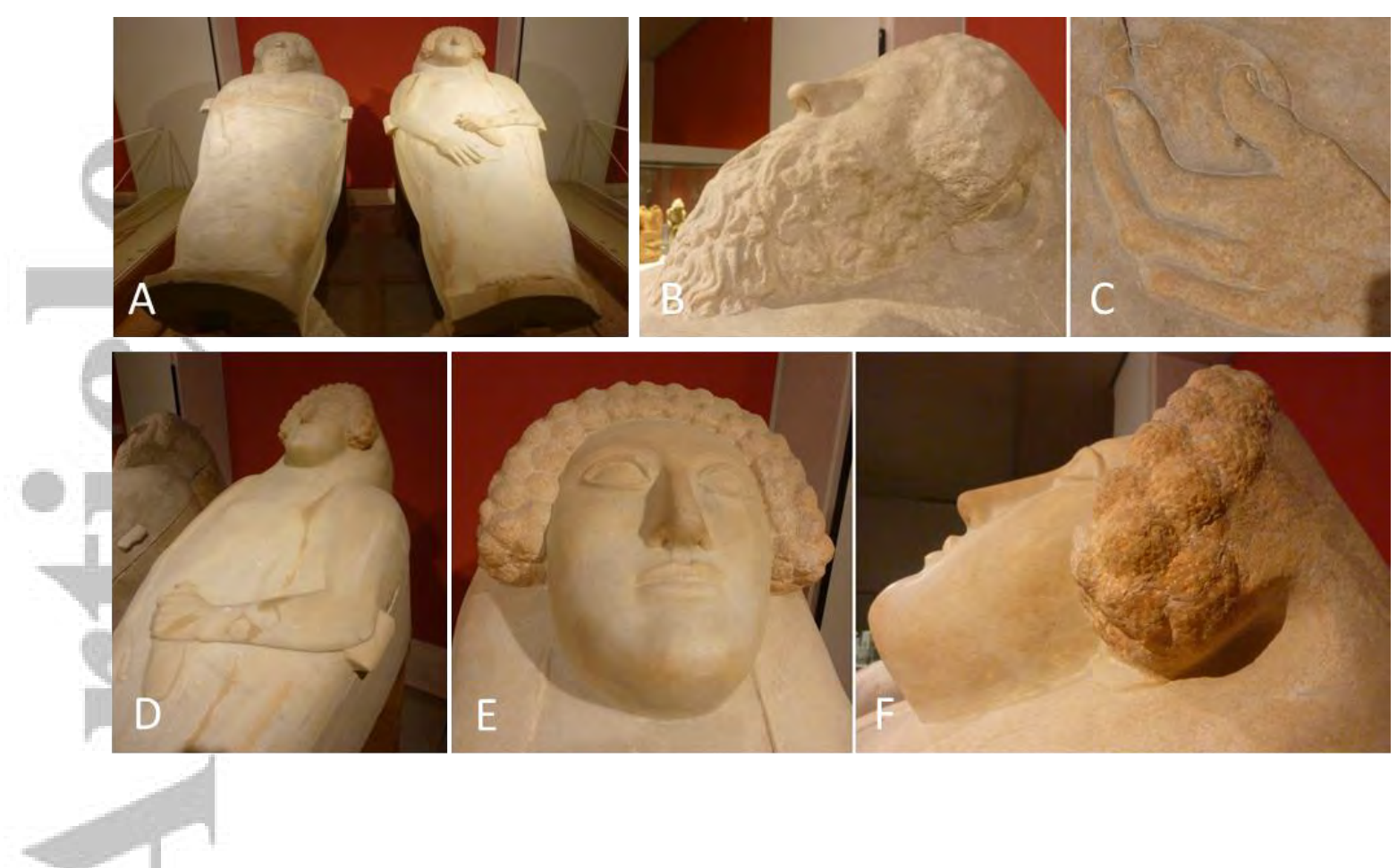

Figure 1. General view of the two anthropoid sarcophagi, the male on the left and the female on the right measure more than $2 \mathrm{~m}$ in length (A). Male sarcophagus: detail of the head and beard (B) and of the half-clenched hand holding a fruit (C). Female sarcophagus: detail of the repairs $(\mathrm{D})$, of the face $(\mathrm{E})$ and of the hair $(\mathrm{F})$. (photos: I. Rodà) 


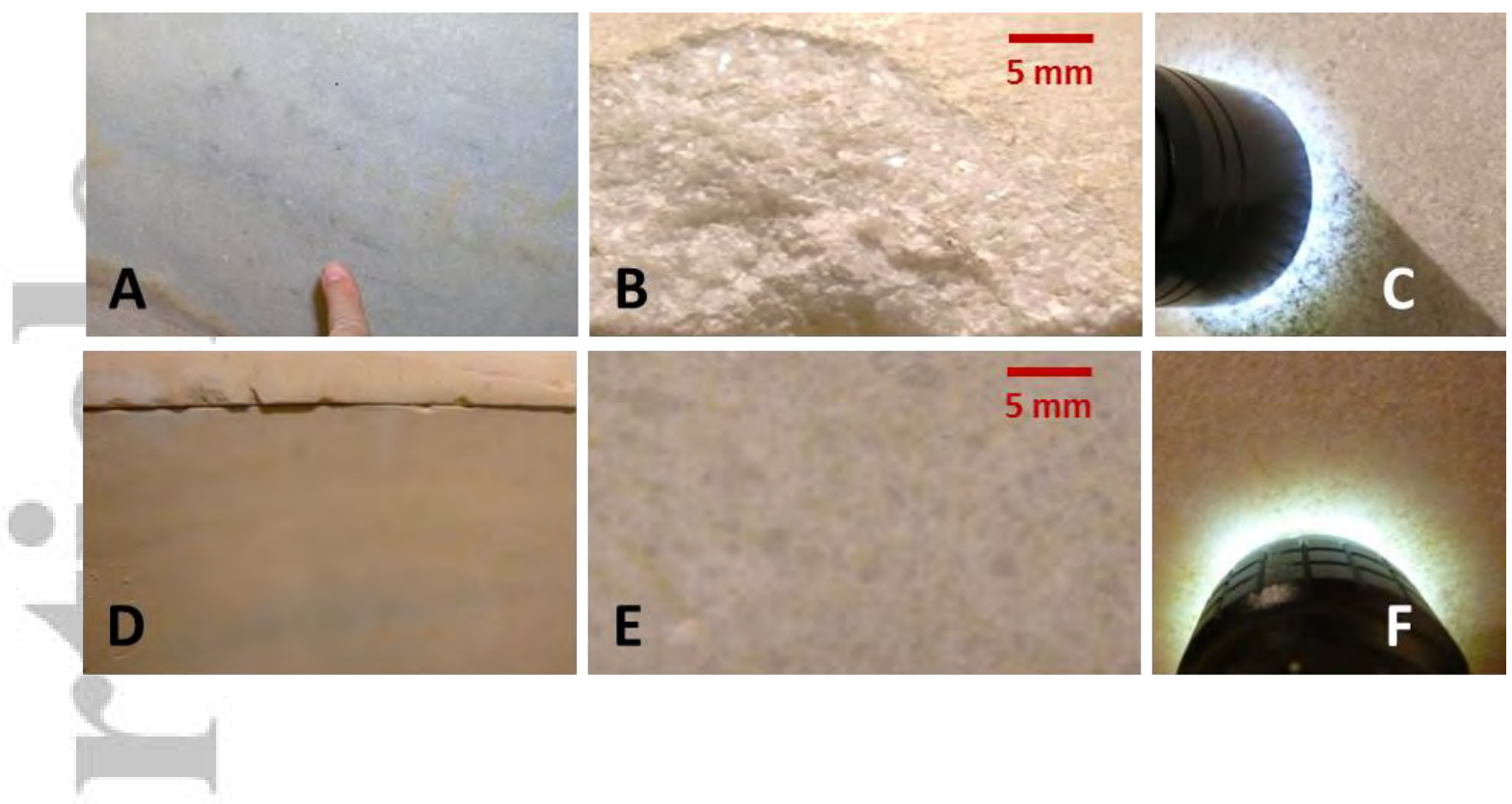

Figure 2. Different macroscopic views of the Male sarcophagus (A), (B) and (C) and of the Female (D), (E) and (F). (photos: P. Lapuente) 


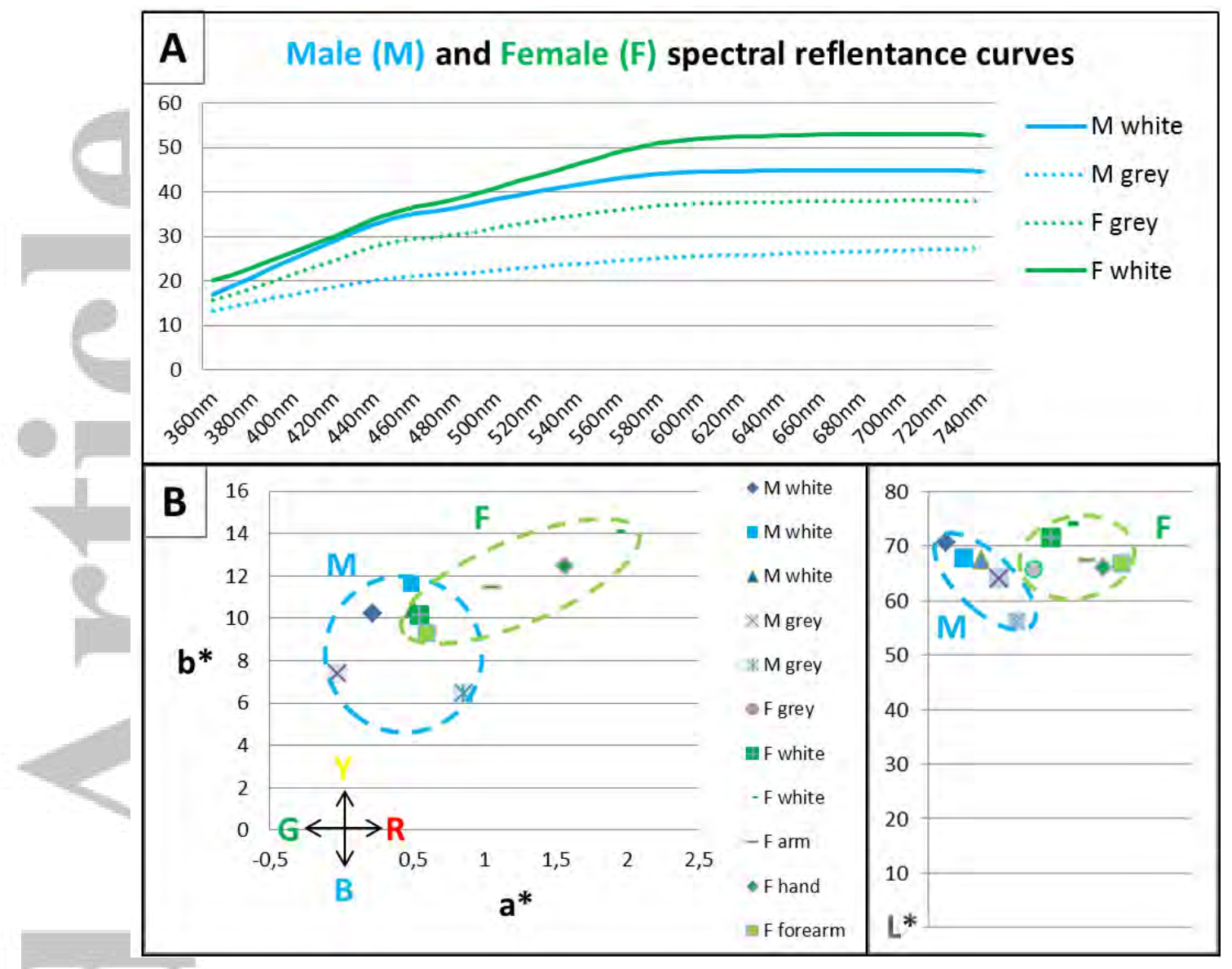

Figure 3. Spectral curves of Reflectance (\%) versus Wavelength for both sarcophagi (A). Representation of CIELAB color space (B) 

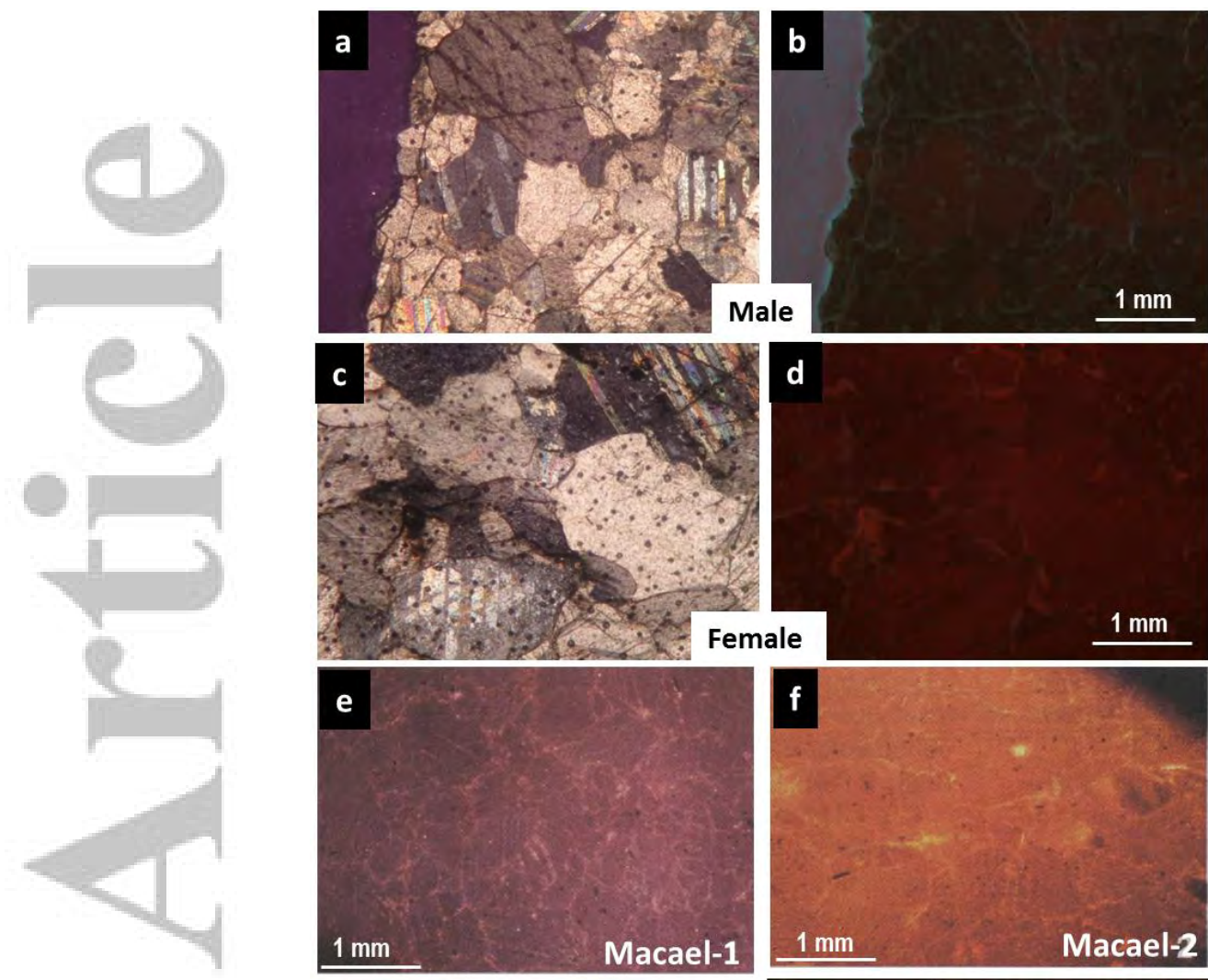

d

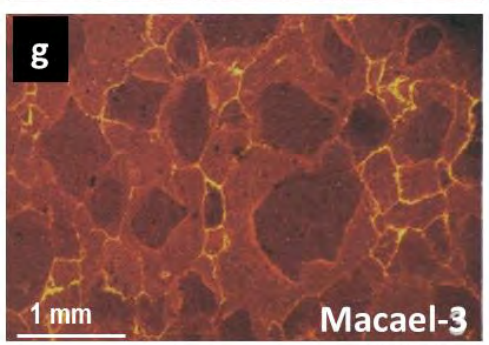

$1 \mathrm{~mm} \quad$ Macael-2
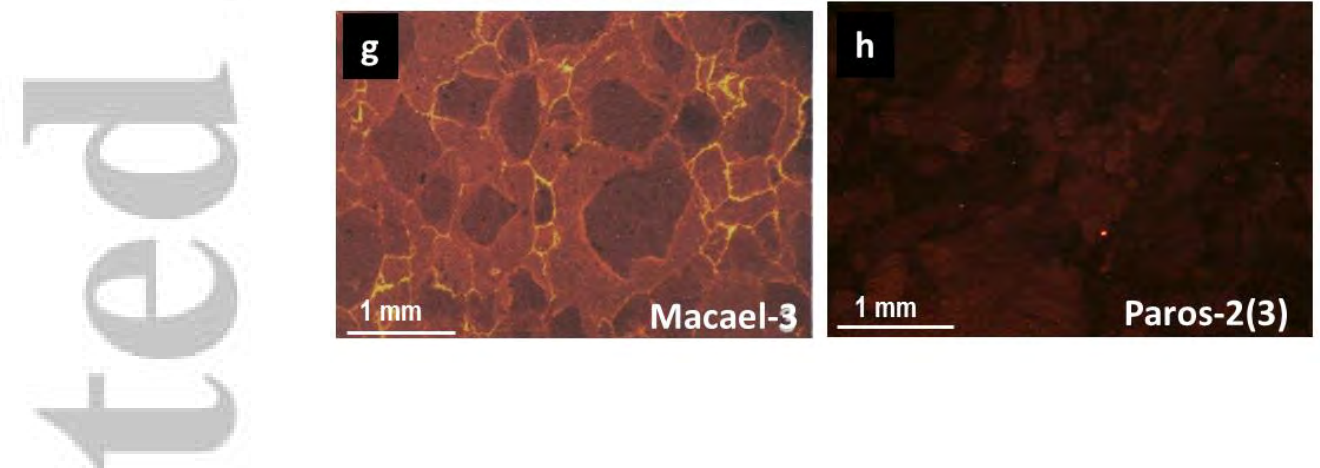

Figure 4. a-b: Petrography in crossed nicols and CL image of the Male sample. c-d: of the Female sample. e-f-g: CL-patterns of different Macael lithotypes. h: CL-microfacies of Paros-2(3), (photos: P. Lapuente) 


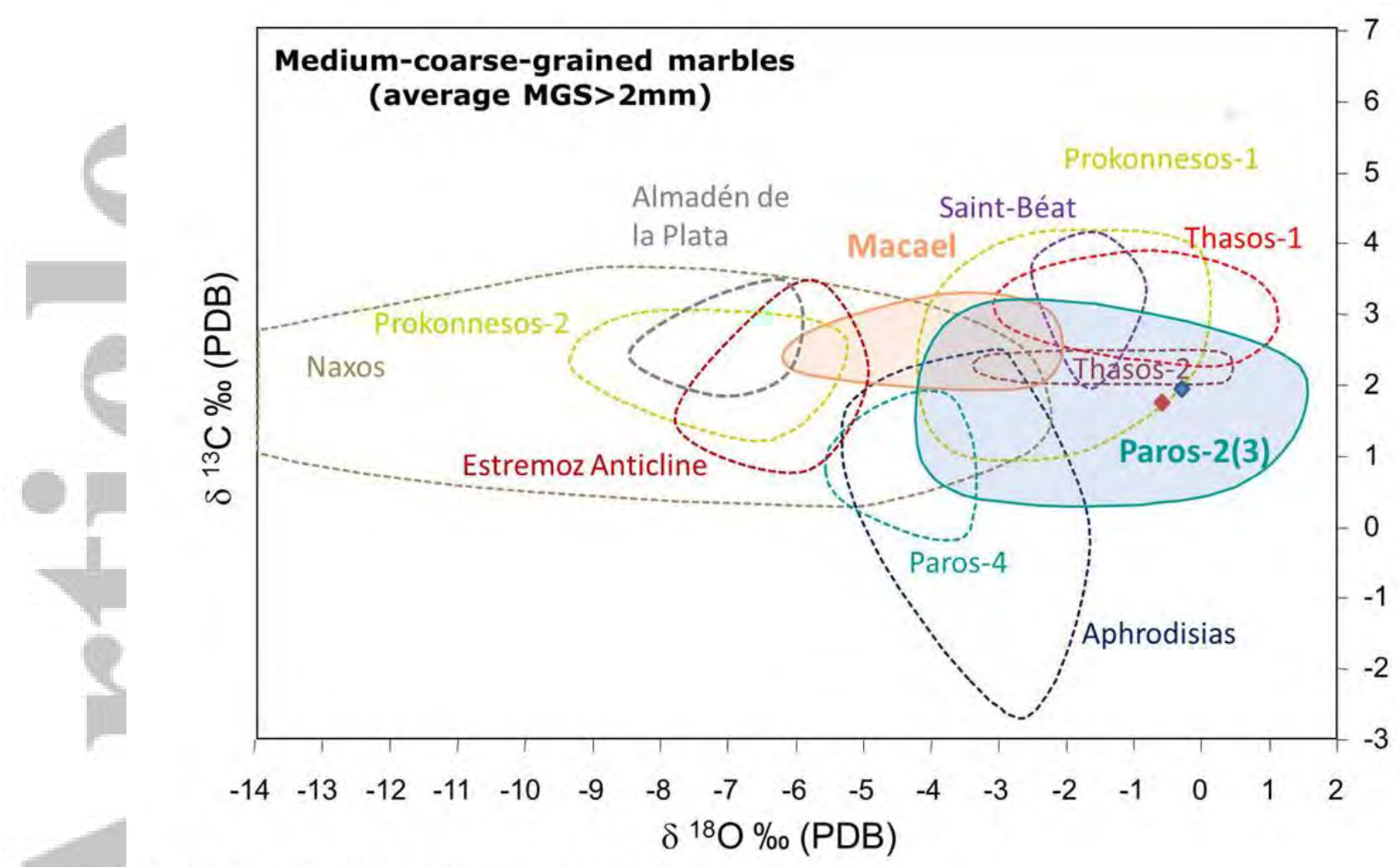

Modified from Gorgoni et al (2002); Lapuente et al (2000; 2014)

Figure 5. Isotopic signature of both sarcophagi (the two dots), which is compatible with Proconnesian and Parian provenance, but totally incompatible with Macael and other Iberian marbles. Each field encircles the isotopic data points obtained from the marble quarry samples after the mentioned papers 